\title{
REKONSTRUSI PEDIDIKAN ISLAM DAN PERAN PESANTREN \\ DALAM MEMBANGUN KEPRIBADIAN MUSLIM YANG KAFFAH
}

\author{
Oleh : Moh. Mundzir dan Isnawati Nur Afifah Latif*
}

\begin{abstract}
Abstrac
Resource development is indeed quite basic as a target human development with all its physical and mental devices. Absorption natural resources and the environment without including source development human power, will result in the growth of excessive exploitation. Even will damage the environment, will also destroy potential sources for humanity's prosperity. But keep in mind that source development human power cannot be separated from community social development. Because what it means is the abundance of natural resources, without a form of society harmonious. Morally how it involves social spirituality in managing their social environment by utilizing existing resources. So the Islamic boarding schools must be more open and flexible in seeing social reality, nature and the environment and its institutional system, with all progress and the development of science and technology in practice must be able to educate and prepare qualified human resources in accordance with the demands of the times.

In the life of the Islamic boarding schools there are values, ethos and culture in fact, it is very appropriate to develop a noble attitude. The values developed are for example: the values of monotheism, humanity, justice and honesty, concern for other beings, independence and unity and others. Islamic boarding schools with ethos that are carried, do good deeds according to the needs and aspirations of the community. On the basis of the aims of guiding and maintaining harmony, boarding schools appear and grow without waiting and hoping for rewards from anyone. This is what later gave birth to a large number of Islamic boarding schools with all their strengths and limitations
\end{abstract}

Keywords: Islamic Education, Islamic Boarding School, Moslem Personality.

*Moh. Mundzir dan Isnawati Nur Afifah Latif adalah Kaprodi dan Sekprodi PAI Sekolah Tinggi Ilmu Tarbiyah Makhdum Ibrahim Tuban.

\section{PENDAHULUAN}

Pendidikan pesantren yang berdiri sejak abad ke-16 M, berperan besar bagi kemajuan pendidikan Islam maupun bagi bangsa Indonesia secara keseluruhan. Pesantren merupakan salah satu lembaga pembentuk generasi pewaris bangsa yang bermoral melalui kekhasan budayanya. Institusi pesantren tak lepas dari pengaruh unsur utama yaitu: Kyai, pengurus 
pondok, yayasan dan lembaga yang ada di dalam pesantren, jajaran pengasuh, santri dan alumni, serta unsur bangunan fisik lainnya. Kyai berada pada unsur pusat dalam komunitas pesantren sebagai pemimpin kegiatan keagamaan seperti imam sholat berjamaan, wiridan, dan sebagainya. (Dhofier, 1982)

Pada awal berdirinya, pesantren mengajarkan agama sebagai materi ajar. Konsentrasi bidang agama yang dimiliki tiap pesantren berbeda-beda. Pangkala data pondok pesantren menyebutkan konsentrasi bidang keagamaan di pesantren meliputi aqidah/tauhid, fiqih/ushul fiqih, tasawuf, tafsir, hadis, tahfidzul quran, ilmu hisab/falaq, nahwu/sharaf, pendidikan kader ulama/ustadz, bahasa arab, dan lain sebagainya. Sejak tahun 90an, banyak pesantren yang menjadi pusat pengembangan dan pengabdian masyarakat.

\section{Rekonstruksi Pendikan Islam}

Dengan jumlah tak kurang dari 23.000 buah, dengan sejarah-nya yang panjang, lembaga pesantren sangat signifikan bagi pengembangan nilai-nilai, ilmu pengetahuan, disamping pegembangan skill serta produsen tokoh-tokoh kaliber regional, nasional maupun internasional.

\section{Tipologi Pesantren}

Sejalan dengan perkembangan zaman, pesantren mengalami perubahan. Sebagian pesantren tetap mempertahankan pola pendidikan pesantren salaf, tetapi sebagian yang lain bersikap kooperatif terhadap perubahan. Untuk itu, ada dua tipologi pesantren dari sudut pandang ilmu pengetahuan yang diajarkan, yaitu (1) salaf, dan (2) khalaf.

\section{Permasalahan Pesantren}

Terdapat pertanyaan yang menggelitik bagi dunia pesantren:

1. mengapa pada saat jumlah pesantren yang kian meningkat dan berkembang, tapi belum mampu menghasilkan kader ulama yang potensial seperti para pendahulunya?

2. Mengapa pondok pesantren terdahulu dengan segala keterbatasannya mampu menghasilkan Ulama yang kaffah bil ilmi wal amal?

Pertanyaan diatas cukup sederhana, mungkin saja tidak terlintas dibenak pemangku pesantren, karena hampir semua pesantren sedang terlena menggeloranya pengembangan, pembaruan dan inovasi disegala bidang. 
Akan tetapi mereka justru lupa dan bahkan kehilangan ruh dan cita-cita mulia pesantren yang sesungguhnya, yakni mencetak kader ulama yang tafaqquh fiddin. Oleh kerana itu paparan ini akan mencoba mendeksripsikan dinamika pendidikan pesantren, dan sekaligus jawaban atas persoalan persoalan yang sedang mendera.

\section{Persoalan yang Dihadapi dan Rekonstruksi Pendidikan Pesantren}

\section{Dinamika Pendidikan Pesantren}

Eksistensi pesantren sebagai lembaga pendidikan Islam tentu tidak diragukan lagi, namun pergolakan dan dinamika kehidupan masyarakat yang semakin kompleks, semakin mendewasakan pesantren untuk bersifat arif dalam menyikapinya. Namun demikian bukan berarti langkah pesantren tanpa kelemahan, melainkan meghadapi sederet persoalanpersoalan yang belum menemui penyelesaian.

\section{Beberapa Faktor Penyebab}

Hasil riset menunjukkan terdapat beberapa faktor yang menyebabkan kondisi tersebut bisa terjadi:

\section{a. Formalisasi Pendidikan Pesantren}

Pada dekade awal beridirinya pesantren, secara kelem-bagaan bersifat independen artinya pesantren berhak mengelola secara menyeluruh segala aspek yg terdapat didalamnya. Akan tetapi sejalan dengan perkembangan dunia pendidikan nampaknya pemerintah mulai melirik, mengadakan pembaruan pesantren dengan gagasan konvergensi kependidikan, membuka sekolah formal pada lembaga pesantren dan memasukkan materi pelajaran umum dengan perbandingan $30 \%$ dan pelajaran agama $70 \%$.

\section{Rasionalisasi Pesantren}

Rasionalisasi dan bentuk formalisasi pesantren merupakan fakta yang tidak bisa dipungkiri, namun seharusnya pesantren memiliki prinsip yang mapan dan kokoh, setidaknya mempertimbangkan bebe-rapa hal, antara lain: Pertama, dengan formalisasi, maka beban belajar santri akan semakin bertambah berat, apalagi dengan kualitas input (santri) yang 
terbatas, Kedua, ketika beban santri semakin berat, memungkinkan timbulnya santri tidak fokus dalam proses penguasaan ilmunya.

\section{Dampak Rasionalisasi}

Perpaduan antar sistem pesantren yang tradisional dan system pendidkan formal dalam beberpa aspek menimbulkan kelemahan, yaitu menyebabkan pesantren mengalami krisis identitas, para santrinya canggung dalam penguasaan ilmu agama (kitab kuning) dan kurangnya penguasaan ilmu pengeta huan umum ketika lulusannya dihadapkan dengan lulusan pendidikan umum. Sedangkan Mujammil Qomar menilai sebagai penyebab melemahnya independensi pesantren; pesantren tidak bisa lagi secara mutlak menentukan kebijakan pendidikannya.

Riset di beberapa pondok pesantren menunjukkan: Pertama, formalisasi terkesan pragmatis, didasarkan pada kebutuhan masyarakat terhadap pesantren dan pertim-bangan jumlah santri; Kedua, formalisasi pendidikan sebagai upaya pening-katan mutu pendidikan pesantren, meski pada kenyataannya telah terjebak pada upaya mempertahankan kelangsungan (survive) pesantren menjadi sebuah sistem pendidikan persekolahan dan madrasah

\section{Globalisasi dan Modernisasi}

\section{b. Tuntutan Globalisasi dan modernisasi.}

Globalisasi dan modernisasi secara tegas dikata-kan sebagai penyumbang terbesar perubahan sosial masyarakat, mulai gaya hidup, cara berfikir, berkomunikasi, cara pemenuhan kebutuhan dll. Perilaku yang sangat nyata ialah perubahan motivasi wali santri/santri dalam memondokkan putra-putrinya. Koentjaraningrat mendefinisikan bahwa modernisasi sebagai proses pergeseran sikap dan mentalitas warga masyarakat untuk bisa hidup sesuai dg tuntutan masa kini.

\section{b. Motivasi Belajar Di Pesantren}

Jika periode sebelum tahun 70an orang tua memon-dokkan anak agar memiliki motivasi agar kelak putra-putrinya menjadi ahli agama, kyai, ulama atau muballigh untuk bisa dimanfaatkan di kampugnya. Namun sekarang semakin kompleks, selain harapan di atas terdapat motivasi lain: 1) memperbaiki akhlak dikarenakan ketidak mampuan orang tua untuk mengawasi, maka dikirimlah ke pesantren, maka tidak heran jika muncul ungkapan 
"pesantren sebagai bengkel akhlak", 2) harapan untuk bisa melanjutkan ke perguruan tinggi agama yang baik, 3) memiliki keterampilan untuk bekerja.

\section{c. Keterbatasan Masa Studi yang relatif singkat.}

Keberahasilan para ulama terdahulu kaffah dalam bidang ilmu agama, ialah mau berusaha keras, waktu berlajar yang relatif lama dan bahkan berpindah-pindah dari pesantren satu ke pesantren yang lain. Situasi ini sulit dijumpai di pesantren yang memiliki pendidikan formal, karena siswa dibatasi oleh masa studi, usia siswa. Secara logika dg waktu yang hanya 3 s/d 6 tahun, dan beban belajar sedemikian banyak, kemampuan berfikir terbatas, maka cukup sulit jika ingin melampui atau minimal menyamai standar penguasaan keilmuan para kyai ulama terdahulu.

\section{d. Kurangnya pendekatan spritual.}

Proses pendidikan pesantren secara umum dapat dilakukan dengan berbagai metode, dan pendekatan yang disesuaikan dengan kemampuan/kesiapan santri belajar. Beberapa pendekatan seperti psikologis, struktural, personal maupun kelompok. Bagi pesantren yang mengadopsi sistem pendidikan formal, maka pendekatan, metode semua bernuansa modern dan terencana, rasional dan terstruktur. Bagi pendidikan non pesantren upaya tersebut dianggap cukup dan memenuhi standarisasi lembaga formal. Namun bagi pesantren itu belum cukup sampai disitu, dibutuhkan pendekatan spiritual yang menjadi ciri khas pesantren.

\section{Rekonstruksi Pendidikan Pesantren dalam Membangun Kepribadian Muslim yang Kaffah}

\section{a. Rekonstrusksi Tujuan Pendidikan}

Dalam penyelenggaraan pendidikan, penetapan tujuan merupakan bagian paling fondamental, karena la akan menentukan arah, isi, dan langkah pendidikan yang akan dikembangkan. Dalam formulasi tujuan tidak akan terlepas dari nilai-nilai yang dianut oleh pelaku pendidikan itu sendiri. Maka tidaklah heran antara satu lembaga pendidikan dengan lainnya memiliki tujuan yang berbeda, karena berbedanya kepentingan yang ingin dicapai.

Prinsip dasar menempatkan tujuan pesantren, adalah bahwa output pesantren harus bisa memberikan warna bagi masyarakat, memberikan solusi persoalan-persoalan. Yang menjadi masalah adalah masyarakat memiliki tuntutan yang berbeda-2, sehingga mendorong pesantren melakukan pembaruan, perombakan sistem pendidikan. Ironisnya jutru output 
semakin tidak jelas. Ilmu umum tidak bisa matang, pengetahuan agama (baca kitab) sangat minim. Disisi lain upaya perombakan ataupun pembaruan tidak dipersiapkan dg matang menyentuh aspek subtansial, melainkan hanya menarik minat masyarakat supaya terpikat akan tetapi ketika jumlah santri meningkat, penanganan kurang maksimal.

Menyikapi dinamika yang ada, maka sudah waktunya pesantren kembali pada khittoh awal, sebagai Lembaga pencetak ahli-ahli agama dan ulama: pertama, melahirkan insan yang mutafaqqih fiddin; kedua, menghayati dan mengamalkan ajaran Islam dg tekun, ikhlas semata-2 berbakti, mengabdi kpd Allah SWT; ketiga, menghidupkan sunnah Rasul dan menyebarkan ajaran-ajarannya secara kaffah; keempat, berakhlak luhur, berpikir kritis, berjiwa dinamis, dan istiqamah; dan kelima, berjiwa besar, kuat mental, fisik, sederhana, tahan uji, tawaddu', kasih sayang terhadap sasama, mahabbah dan khasyah serta tawakkal kepada Allah SWT.

Perlu dipertegas bahwa bukan berarti pesantren harus membumi haguskan rumusanrumusan tujuan yang ada, melainkan seberapapun banyak tujuan pesantren, yang harus menjadi prioritias ialah pencetak kader ulama, karena ulama merupakan pewaris nabi dan juga sebagai khalifatul fil ardi

Dengan demikian, tujuan pendidikan pesantren harus diarahkan dalam rangka menjadikan santri sebagai khalifatullah mampu menjalankan tugas kepemimpinan di muka bumi, beribadah sebagai hamba Allah, berakhlak mulia, dan mengembangkan segenap potensi kehidupan nya, sehingga dapat memperoleh keselamatan dan kese jahteraan hidup di dunia dan akhirat.

\section{b. Reformulasi Kelembagaan.}

Reformulasi kelembagaan pesantren merupakan alter-natif berikutnya, sebagai perpanjangan atas perubahan tujuan pendidikan, kerena perubahan tujuan tanpa wadah atau lembaga yang memiliki nafas yang sama, akan terjadi kekaburan atas tujuan dan target itu sendiri. Dengan kata lain tidak mungkin pembentukkan kader ulama diserahkan pada lembaga formal seperti SMP/ MTs, SMA/ MA, karena mereka punya beban menstadarkan dg kurikulum nasional, tidak mungkin sebuah lembaga mampu memberlakukan dua kurikulum yang berbeda dengan beban dan kajian yang berbeda.

\section{c. Rekonstruksi kurikulum}


Kurikulum pesantren erat kaitannya dengan kitab salaf, (kitab kuning). Fakta menunjukkan bahwa pesantren yang memiliki pendidikan formal seperti SMP/MTs, SMA/MA, kitab salaf hanya sebatas pada aspek menjaga kekhasan/tradisi pesantren, bukan sebagai pusat kajian secara utuh dan mendalam. Situasi ini wajar, karena institusi punya kewajiban utama untuk menyesuaikan dengan standar nasional pendidikan, sementara yang lain dinilai sebagai muatan lokal, yang sewaktu-waktu bisa berubah

\section{Potensi Manusia}

Pada kajian yang dikembangkan Barat, menyatakan bahwa perkembangan manusia dipengaruhi oleh faktor bawaan (naitvisme). Kemudian muncul berikutnya berkembang kajian teori yang mengajarkan bahwa perkembangan manusia ditentukan oleh lingkungannya (empirisme). Kajian teori ketiga sebagai sintesis dari teori sebelumnya, menyatakan bahwa perkembanga seseorang ditentukan leh pembawaan dan lingkungan (konvergensi).(Purwanto, 1992: 14-15).

Abdul Aziz (1988: 64) menyebutkan dalam konsep Islam, konvergensi inilah yang mendekati kebenaran, sebagaimana sabda Nabi Muhammad yang artinya; "Dari Aswad bin Muroba', sesungguhnya Nabi SAW. Bersabda: Setiap anak dilahirkan dalam keadaan fithrah sampai dia mengucapkan (sesuatu) yang bisa mengubah kesuciannya, karena Ibu-Bapak (orang tuanyalah) yang menjadikan anak tersebut Yahudi, Nasrani, ataupun Majusi (HR. Abu Ya'la, Thabrani, dan Baihawi). Menurut hadis tersebut, manusia membawa kemampuankemampuan. Kemampuan inilah yang disebut pembawaan.

Ahmad Tafsir ( 1991: 35) juga sepakat dengan pemaknaan fitrah yang dimaksud dalam hadis tersebut di atas adalah potensi. Potensi adalah kemampuan. Jadi, fitrah yang dimaksud sama dengan pembawaan. Sedangkan Ibu Ayah adalah lingkungan sebagaimana yang dimaksud para ahli pendidikan. Kedua faktor inilah yang menentukan perkembangan seseorang.

\section{Dimensi-dimensi Peningkatan Kualitas Sumber Daya Manusia dalam Islam}

Sejumlah ayat di dalam Al Quran menjelaskan bahwa kualitas Sumber Daya Manusia (SDM) dicapai jika individu berada pada tingkat Ulul Albab, sebagaimana disebutkan dalam QS. Ali Imron ayat 191. Eminensi Ulul Albab adalah pribadi yang mampu berdaya guna dan berhasil gua dalam tiga aktifitas, yaitu dzikir, fikir, dan fi'il (berkarya). Kemampuan berdzikir berarti selalu sadar sebagai hamba Allah. Kemampuan berpikir Ulul Albab berarti berpikir 
tentang penciptaan penciptaan langit dan bumi yang ditunjukkan dalam aktifitas nyata mencakup tindakan penelitian untuk mengetahui kebesaran Allah. Kemampuan fi'il merangkum tiga dimensi. Pertama profesionalisme; kedua, transenden berupa pengabdian dan keikhlasan; ketiga, kemaslahatan bagi kehidupan yang didasari rasa tanggungjawab.

Menurut Tolhah Hasan (1987: 185), ada tiga dimensi yang harus diperhatikan dalam usaha peningkatan kualitas umat, yaitu:

1. Dimensi kepriadian sebagai manusi, ditunjukkan melalui kemampuan untuk menjaga integritas, sikap, tingkah laku, etika dan moralitas yang sesuai dengan pandangan masyarakat.

2. Dimensi produktifitas, yaitu ada suatu hasil yang dilakukan dari usaha individu. Usaha yang dilakukan semakin banyak, maka kualitas yang ditunjukkan semakin baik.

3. Dimensi kreatifitas, yaitu kemampuan seseorang untuk berpikir dan berbuat kreatif, menciptakan sesuatu yang berguna bagi dirinya dan masyarakat.

\section{Kepribadian Muslim}

Menurut kajian para ahli, muslim yang memiliki pribadi yang berkualitas memiliki ciri sebagai berikut:

a. Memiliki jasmani dan rohani yang kuat

Kekuatan jasmani dan rohani menunjang individu untuk mampu melaksanakan aktivitas hidupnya dengan baik. Islam menganjurkan segala sumber daya yang dimiliki oleh jasmani dan rohani harus sehat dan kuat. (Zaini, 1986: 48)

b. Memiliki keterampilan yang memadai

Muslim diharapkan memiliki keterampilan yang memadai agar jasmani dan rohani yang sehat dan kuat dapat bermanfaat bagi kehidupan. Sebagaimana disebutkan dalam QS. Al Anfal ayat 60. (Yunus, 1986: 167)

c. Memiliki intelektual yang cerdas

Maksud dari intelektual yang cerdas disini adalah akal yang menguasai ilmu pengetahuan dan teknologi juga kreatif sehingga keterampilan yang dimiliki dapat bermanfaat. Quran surat Ali Imron ayat 190-191 menjelaskan tentang manusia diperintahkan menggunakan sumber daya intelektualnya dengan kegiatan berdzikir dn berfikir tentang segala ciptaan Allah di alam ini. Sehingga manusia mampu memperoleh kesimpulan bahwa semesta ini bermanfaat seutuhnya.

d. Melikiki semangat, kesungguhan kerja dan profesiaonal 
Penguasaan ilmu pengetahuan dan teknologi yang dimilikinya mengharuskan untuk direalisasikan dalam kehidupan. Harus mengerjakan perbuatan dengan sebaik-baiknya dan sungguh-sungguh serta dikerjaka secara profesional sehingga bermanfaat bagi dirinya, keluarga, masyarakat, maupun negara. Bekerja dengan kesungguhan harus didasari dengan profesionalitas agar mencapai kesuksesan. (Zaini, 1995: 40)

e. Memiliki akhlak mulia dan berdisiplin

Melaksanakan sesuatu haruslah disesuaikan dengan norma-norma yang tinggi. Oleh karena itu kualitas sumber daya manusia dituntut untuk memiliki akhlak mulia dan disiplin. Islam pun menganjurkan agar manusia melaksanakan pekerjaan harus dengan cara yang baik, yang berarti harus memiliki nilai moral dan akhlak. Jika hal ini tidak dipatuhi akan terjadi pelanggaran nilai-nilai agama yang dapat membahayakan kehidupan bermasyarakat, bangsa bahkan bagi dirinya sendiri. (Zaini: 116)

f. Memiliki pendirian yang teguh (istiqomah dan bertanggung jawab)

Muslim dituntut memiliki pendirian teguh baik dalam ucapan maupun perbuatan. Hal ini dimaksud agar tidak mudah terjerumus dalam hal-hal yang mencelakakan dirinya. Setelah berpendirian teguh, diajarkan pula mempertanggungjawabkannya. Jika ucapan dan perbuatan baik, maka harus dipertahanka ahkan ditingkatkan. Jika belum baik harus segera diperbaiki.

g. Mimiliki kemanan dan ketaqwaan yang kuat terhadap Allah

Muslim yang ideal juga beriman dan bertaqwa kepada Allah dengan benar melalui hati yang tunduk, patuh, dan taat menjalankan agamanya dengan amal ibadah baik bersifat duniawi seperti bekerjakeras untuk memnuhi kehidupannya, membangun bangsa dan negaranya, maupun amalan ukhrawi seperti sholat, zakat, puasa dan haji. Taqwa juga memlihara diri dari amarah Allah dengan menjalankan perintahNya. (Nasution, 409)

\section{Pondok Pesantren Pembentuk Kepribadian Muslim yang Kaffah}

Pembangunan sumber daya manusia tidak terlepas dari pengembangan sosial kemasyarakatan. Secara moril sebagaimana melibatkan spiritualitas sosial dalam menata lingkungan sosial dengan memanfaatkan sumber daya yang ada. Pesantren harus lebih terbuka dan fleksibel melihat realitas sosial, alam, dan lingkungan serta sistem kelembagaannnya. Dengan segala kemajuan dan perkembangan ilmu pengetahuan juga teknologi, secara praktik harus mampu mendidik dan menyiapkan sumberdaya manusia yang berkualitas sesuai dengan tuntutan zaman. (Hasyim, 1988: 95) 
Kehidupan pesantren yang penuh dengan nilai-nilai, etos, dan budaya sesungguhnya sangat tepat untuk membangun peradaban yang luhur. Nilai yang dikebangkan di pesantren diantaranya nilai ketauhidan, kemanusiaan, keadilan dan kejujuran, kepedulian terhadap makhluk lain, kemandirian, dan kebersahajaan. Pesantren dengan etos yang disandang, melakukan amal saleh sesuai dengan kebutuhan dan aspirasi masyarakat. Agar keharmonisan bermasyarakat terjaga, pesantren tampil dan tumbuh tanpa menunggu dan berharap imbalan. Inilah yang kemudian melahirkan pesantren dalam jumlah besar dengan kekuatan dan kekhasannya. (Suprayogo, 2004: 223)

Tumbuh kembang pesantren telah mendapat pengakuan dari masyarakat. Keunikan sistem dan segala potensinya menjadikan pondok pesantren tetap bangkit dan dianggap sebagai solusi alternatif bagi kehidupan bermasyarakat yang modern. Keberadaan pondok pesantren sebagai lembaga pendidikan Islam berusaha menjawab segala tantangan perubahan zaman dengan melakukan pembenahan dan pembaharuan pada sistemnya.

Pondok pesantren sebagai salah satu lembaga pendidikan Islam non formal memiliki potensi dan kedudukan juga peran penting. Sifat kekeluargaan dan keakraban yang menjadi ciri khas pondok pesantren menjadikan masyarakat percaya bahwa pondok pesantren mampu mempertahankan nilai-nilai tradisi yang baik dan mengambil sesuatu yang baru dengan lebih baik.

Sebagai solusi alternatif masyarakat, pondok pesantren telah dianggap mampu mewujudkan manusia seutuhnya yang memiliki kemampuan dan keterampilan dalam penguasaan ilmu pengetahuan dan teknologi. Hal ini dapat dijumpai pada perkembangan pondik pesantren yang mulai membekali santri didiknya dengan berbagai kegiatan yang mengarah pada tujuan pembentukan kepribadian tersebut. Dengan demikian, anggapan bahwa pondok pesantren kuno dan tertinggal menjadi terhapus.

\section{KESIMPULAN}

Semangat pembaruan, perubahan, inovasi pendidikan di pesantren menjadi keharusan karena itu konsekwensi logis dari era globalisasi dan modernisasi. Akan tetapi mempertahankan atau menjaga ruh pesantren sebagai "lembaga pengkaderan calon Ulama" tentu jauh lebih penting. Oleh karena hal ini sesuai kaidah "almuhafadoh ala qodimissholih wal akhdudu bil jadidil aslah " (menjaga tradisi lama dan mengambil hal baru yang lebih 
baik). Sehingga antara pengapdosian nilai-nilai baru seimbang dg nilai-nilai lama yang menjadi subtansi pokoknya.

Kualitas manusia Indonesia perlu diprioritaskan pada pembangunan jangka panjang. Kualitas sumber daya manusia yang dimiliki suatu bangsa dapat dilihat dari sinergistik kualitas jasmani dan rohani yang dimiliki individu masyarakat. Dalam istilah lain hal ini disebut sebagai dimensi fifik dan non fisik. Melaui pondok pesantren, dimensi-dimensi ini dapat dibentuk dari kegiatan-kegiatan yang menjadi kurikulum di dalamnya.

\section{DAFTAR PUSTAKA}

Aziz, Abdul. 1988. Hadits dan Ilmu Haidts untuk MA. Semarang: Penerbit Wicaksana.

Dhofier, Zamakhsyari. 1982. Tradisi Pesantren. Jakarta: Sinar Harapan.

Hasan, Tolhah. 1987. Islam dalam Berbagai Perspektif. Jakarta: PT. Galesa Nusantara.

Hasyim, M. Yusuf. 1988. Peranan ddan Potensi Pesantren dalam Pembanguna. Jakarta: P3M.

Madjid, Nurcholis. 1997. Bilik-Bilik Pesantren Sebuah Potret Perjalanan. Jakarta:

Paramadina.

Mastuhu. 1994. Dinamika Sistem Pendidikan Pesantren. Jakarta: INIS.

Nasution, Harun. Tanpa tahun. Islam Rasional, Gagasan dan Pemikiran. Bandung: Mizan.

Purwanto, Ngalim. 1992. Psikologi Pendidikan. Bandung: Remaja Rosda Karya.

Rahardjo, M. Dawam. 1985. Pergulatan Dunia Pesantren Membengun dari Bawah. Jakarta: P3M.

1985. Pesantren dan Pembaharuan. Jakarta: LP3S.

Rahardjo, Sudjono. 1982. Profil Pesantren. Jakarta: LP3S.

Suprayogo, Imam. 2004. Pendidikan Berparadigma Al Quran. Malang: UIN Malang Press.

Tafsir, Ahmad. 1991. Ilmu Pendidikan dalam Perspektif Islam. Bandung: PT. Remaja Rosydakarya.

Wahjoetomo. 1997. Perguruan Tinggi Pesantren. Jakarta: Gema Insani Press. 
Yunus, Mahmud. 1986. Terjemahan Al Quran Karim. Bandung: PT. Al Ma’arif)

Zaini, Syahminan. 1986. Prinsip Dasar Konsepsi Pendidikan Islam. Jakarta: Kalam Mulia. 1995. Kehidupan Sosial Seorang Muslim. Jakarta: Kalam Mulia.

Tanpa tahun. Penyakit Rohani dan Pengobatannya. Surabaya: al Islah. 